\title{
Autumn Sonata: a film written and directed by Ingmar Bergman
}

\section{Joyce Almeida}

\begin{abstract}
SUMMARY
Ingmar Bergman was a Swedish director, writer and producer for film, stage and television. He directed 62 films, most of which he also wrote. Many of his films were set in the landscape of Sweden and he explored the themes of death, illness, cruelty, betrayal, mental illness, religion, and relationships between partners, children and their parents. Known as an auteur, he frequently used his film-making to examine issues from his own childhood.
\end{abstract}

\section{DECLARATION OF INTEREST}

None.

In his film Autumn Sonata, made in 1978, Bergman explores a mother-daughter relationship in which the mother Charlotte, who is a famous concert pianist and also a narcissist, has not seen her adult daughter Eva for 7 years. When they meet, at Eva's request, Charlotte is confronted about her failings as a mother when Eva and her sister were growing up. Charlotte is played by Oscar-nominated Ingrid Bergman and Eva is played by Liv Ullmann.

\section{Biography}

Ernest Ingmar Bergman was born in Uppsala, Sweden, on 14 July 1918. His mother was a nurse and his father a Lutheran minister. Bergman grew up surrounded by religious imagery and discussion. His father, according to Bergman and others, was a conservative parish minister with strict parenting habits, who maintained a capable, confident exterior to his parishioners but was often depressed and moody privately. As a child, Bergman was locked up in dark closets or beaten as a punishment by his father.

In his autobiography Laterna Magica, published in 1987, Bergman states that his interest in films and cinema began early, at the age of 9 , when he traded a set of tin soldiers with his brother for a magic lantern, a possession that altered the course of his life (Bergman 1988 reprint).

A film that he saw about death, at the age of 15 , reinforced his attraction to the cinema as a means of exploring important themes and he certainly focused on the subject of death throughout his film-making career. He repeatedly described himself as a complicated and contradictory child, making special reference both to his ambivalent relationship with his mother, whom he adored but feared was trying to abandon him, and his resentment of his harsh, humiliating, narcissistic (Bergman's own term) father (Macnab 2009). The anger with his father resulted in a break in their relationship when Bergman started his directing career.

Bergman was known for his angry outbursts and perfectionism in his work and recognised that his anger probably had roots in his relationship with his father, with whom he shared a number of traits.

He briefly dabbled in Nazism in his teenage years, as did many young people in Sweden in the 1930s, but he came to reject it after accepting the reality of the concentration camps and then vowed to have nothing more to do with politics.

He was preoccupied throughout his life with his own childhood experiences and was known for making films with significant autobiographical content. He commonly cast actresses with whom he was romantically involved, thus blurring the boundaries between fantasy and reality. Certain performers have described a sense of discomfort in the closeness that Bergman required when working with him.

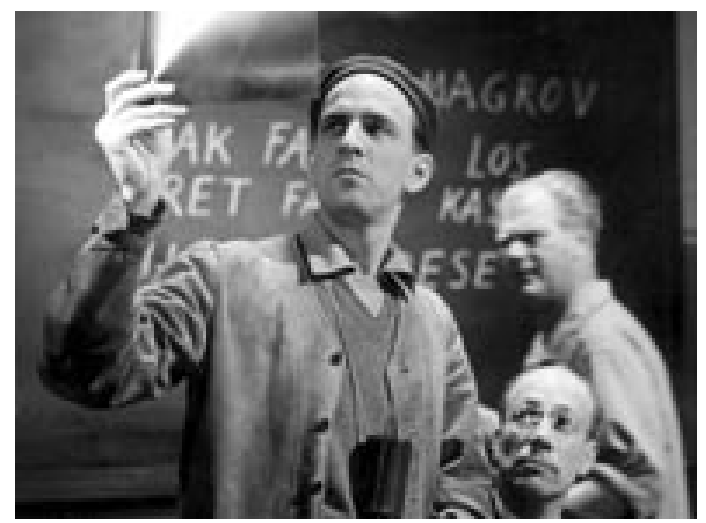

Ingmar Bergman. Taken during the production of Wild Strawberries (Smultronstället) (1957). Svensk Filmindustri (SF) press photo. Source: Svenska Filminstitutet.
Joyce Almeida is a consultant psychiatrist at The Priory Ticehurst House Hospital and at The Priory Grange Heathfield, both in East Sussex. She has an interest in psychoanalytically based psychotherapy with older clients. Dr Almeida has recently started a monthly blog, 'Minds on Film', which explores psychiatric conditions and mental health issues as portrayed in a selection of readily available films (www.rcpsych.ac.uk/ mentalhealthinfo/mindsonfilmblog. aspx). Correspondence Dr Joyce Almeida, The Priory Ticehurst House, Ticehurst, Wadhurst, East Sussex TN5 7HU, UK. Email: dr.jhalmeida@ googlemail.com 


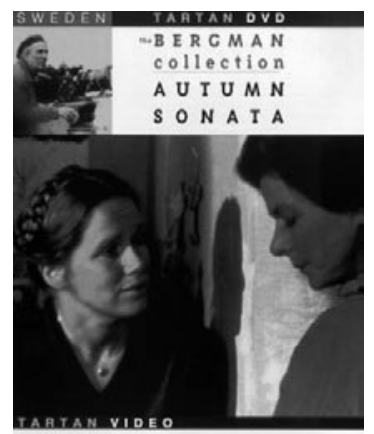

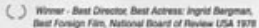

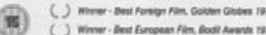

Autumn Sonata (Höstsonaten) DVD. Reproduced with thanks to Palisades Tartan.
Bergman was married five times and fathered nine children. Many of his children went on to work as directors, actors and writers. He was so devoted to his professional life that he struggled to spend much time with his children (he also needed to earn sufficient money to support them all).

Autumn Sonata was filmed in Norway because, at that time, Bergman had tax problems with the Swedish authorities. These had begun in 1976 and they led to his exile in Norway for several years. He was officially exonerated in the tax affair in 1979.

Bergman died in 2007, at the age of 89 , on the island of Faro, where he had lived in relative isolation for the last years of his life, in the house he had built in 1967.

\section{Brief synopsis}

Autumn Sonata begins by introducing us to Eva and her older husband, who, in a direct-to-camera address, provides us with some understanding of Eva's uncertain self-identity and her inability to feel truly loved by him. It transpires that Eva has not seen her mother Charlotte for 7 years. On hearing that her mother's companion Leonardo has recently died, Eva decides to invite her to stay. Charlotte, a successful concert pianist, agrees to come and arrives with several large suitcases, planning a lengthy stay. Eva appears delighted at the reunion. Shortly after showing her mother to her room, Eva reveals that her disabled sister Helena has been living with her for the past 2 years, since Eva brought her out of the nursing home where Charlotte had placed her many years earlier. Charlotte's meeting with Helena is painful to watch, revealing a selfish preoccupation with her own emotional pain rather than with that of her disabled daughter. This realisation is hurtful to Eva and it begins the tense discourse between

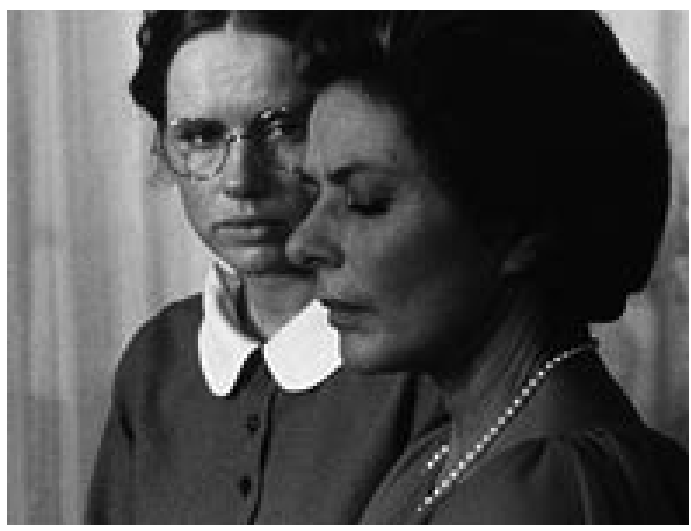

Eva and Charlotte (played by Liv Ullmann and Ingrid Bergman) in the 1978 film Autumn Sonata. Reproduced with kind permission of Personafilm/ltc/The Kobal Collection.
Eva and Charlotte concerning the events of Eva's childhood that have scarred her deeply and burden her still.

It also emerges that, in the 7 years since they last met, Eva had had a son who drowned at the age of 4. Eva is shown suffering from unresolved grief for her child and the relationship she had with him is clearly contrasted with her own early experiences as a girl.

The tension between mother and daughter builds to the climax of the film when Eva, after drinking plenty of wine one evening, tells her mother how she really feels about her neglectful parenting. Eva accuses her mother of being completely absorbed in her music, resulting in an unbearable absence from her early life. Eva goes on to say how much she hated being controlled by her mother, at the age of 14 , when Charlotte returned to the family home for a longer period of time. The film concludes their conversation with a shot of Charlotte lying on the floor. The shot is intercut with a sequence showing the disabled Helena throwing herself out of bed and wriggling along the landing, leaving the powerful image of Eva as adult carer for both her sister and her mother. Their frank discussion leaves Eva once more struggling to resolve feelings of guilt at hurting her mother, aware that she is unable to escape the burden of responsibility that she has always felt for her mother's happiness.

As the films closes, Charlotte is seen flirting with the next target of her affection. She expresses the realisation that she cannot feel happy anywhere. Eva, in contrast, is seen at her son's graveside, contemplating suicide.

\section{Relevance to psychiatry}

This film brilliantly portrays an individual, Charlotte, suffering from a narcissistic personality disorder, superficially competent and successful but, on closer inspection, self-absorbed, lacking in empathy, and needing love and attention from those around her to fill a void inside of loneliness and low self-esteem. By exposing the fraught relationship between narcissistic parent and adult child the film demonstrates the often painful continuation of a desire for attention and meaningful love from a parent who is too self-absorbed and lacking in empathy to provide it.

In psychiatry, we take a full personal history in an attempt to build up a picture of the formative experiences that shape our patients. This film provides a wonderful understanding of how significant those early influences can be in moulding personality and the susceptibility to depression, dysthymia and interpersonal difficulties that may burden a person long into their adult life. 
The film painfully portrays the intrapsychic struggle that adults with a narcissistic parent may face and, through flashbacks, explores the origins of these difficulties. Autumn Sonata offers psychiatrists and psychotherapists a window on the genesis of deeply entrenched psychopathology and perhaps offers understanding of why certain patients derive greater benefit from longer-term psychoanalytically based psychotherapies rather than briefer cognitive-behavioural models of therapy.

As part of a training exercise for junior psychiatrists, viewing Autumn Sonata, followed by a guided discussion, might afford excellent opportunities for learning skills that are so difficult to acquire, by nature of the one-to-one relationship that we share with our patients in a psychotherapeutic setting.

For clients and therapists seeking further understanding of the effects of growing up with a self-absorbed parent, the book Children of the Self-Absorbed: A Grown-Up's Guide to Getting
Over Narcissistic Parents (Brown 2008) may be of interest. This book introduces the concept of a 'destructive narcissistic pattern' and explores the effects on a child when either one or both parents have it. The author outlines two different response patterns commonly seen in adult children of the self-absorbed - the 'siege response' and the 'compliant response' - and suggests protective and coping strategies that may help individuals manage their relationships with their parents more effectively.

I would thoroughly recommend Autumn Sonata as a film with tremendous relevance to all psychiatrists and psychotherapists.

\section{References}

Bergman I (1988 reprint) The Magic Lantern: An Autobiography (trans $\mathrm{J}$ Tate). University of Chicago Press.

Brown NW (2008) Children of the Self-Absorbed: A Grown-Up's Guide to Getting over Narcissistic Parents. New Harbinger Publications.

Macnab G (2009) Ingmar Bergman: The Life and Films of the Last Great European Director. I. B. Tauris.

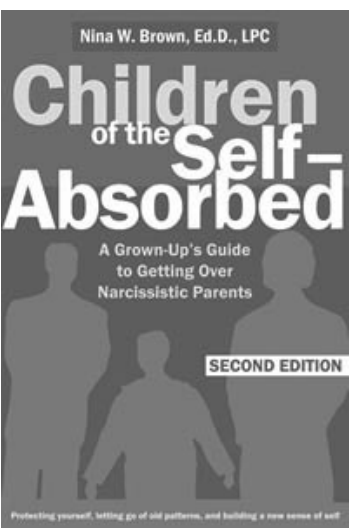

Book cover reproduced with kind permission of New Harbinger Publications 